\title{
QUALIS OF TECHNICAL PRODUCTION: METRIC DEVELOPMENT FOR MANUALS
}

\author{
Qualis de produção técnica: desenvolvimento de métricas para manuais
}

Adhemar Monteiro Pacheco Jr., Carlos José Lazzarini Mendes

\section{A B STRACT}

\begin{abstract}
There are few authors focused on the study of preparing manuals criteria, often criticized for methodological rigor of the information. However, it is interesting to understand what is going wrong; to understand prognosis in self-handling; in prevention of complications; in identifying better services and information; in encouraging the pursuit of excellence in the healthcare. In its preparation should be valued the basic requirements of a manual, which are: 1) wrote in simple words, being concise, efficient, clear with index or table of contents; 2) using the existing institutional rules; 3) being flexible; and 4) having ongoing process of review, update and distribution. In the process of evaluation of Medicine III manuals may have the following stratification: M4 - 100 points: when there is ISBN registration and disclosure in other languages; M3 - 75 points: registration with the ISBN only in our country; M2 - 50 points: registered in regional libraries; M1 - 25 points: manual use for inter-departmental or intra-institutional groups; MO - 0 point: use of manual in intra-departmental teaching. In conclusion, it is known that the use of manuals is focused to the ones who do not know the subject: however, it is also an important tool that can minimize errors, avoid professional misconduct, optimize resources, and at the end allowing assessment of the subject at hand.
\end{abstract}

Key Words - Communication. Manual. Medical education. System support for administrative decisions.

\section{INTRODUCTION}

The beginning of manuals and books may be consid-

ered as those found in art and rupestre rock art caves, cuneiform writing of the Sumerians at 3,000 BC, producing extensive literary work as poems, codes, laws, fables, myths and other narratives, "manualizing" the day by day.

In a big time warp, in imperial Brazil, it can be highlighted the medical manuals done by Pedro Luiz Napoleão Chernoviz (1812-1881), reporting elements of folk lay people medicine, with academic, civilized and hygienic behavior?

There are few authors focused on the study of preparing manuals criteria, often being criticized for methodological rigor on the informations ${ }^{2,3}$.

With regard to the sharing of information to patients, Coulter et al in 1999 highlighted important points that should be included in manuals, such as understanding what is wrong, understand prognosis, self-care, prevention of complications, identification of better services and information, among others, motivating the excellence in manual production and preparation ${ }^{4}$.

\section{MANUAL DEVELOPMENT}

By manual is understand any set of rules, procedures, functions, activities, instructions and guidelines, substantial or essential, making it possible to define and guide the activities to be developed, replicating, spreading and solidifying knowledge and experience.

The preparation of a manual should contain: 1) methodological definition; 2) definition of the premises; 3 ) definition of manual model; 4) choice of procedures, standards and evidence-based guidelines or solid experiences; 5 ) transfer of knowledge to those involved; and 6) monitoring the applicability and validation.

Can be added to it some advantages, which are: 1) important and constant source of information, since updated and reissued; 2) process facilitation in carrying out policies, procedures and functions; assistance in setting criteria and standards; standardizing the basic technique of the process terminology; 3) possibility of appropriateness, consistency and continuity in the rules and procedures; 4) reduction of contradictions and misunderstandings between sectors and multidisciplinary teams facilitating conducts; 5) enable the training of post-graduates; 6) represents an effective instrument for consultation, guidance and training of the institution; 7) prevents improvisations that usually arise in various forms in the institutions; 8) permits permanent revision, updates and objective evaluation, using instructions, standards, technical notes, eg all normative acts adopted by the institution; and 9) permits visibility and standardization of functions, sub-functions and involved activities.

Manual can offer as disadvantages: 1) when not updated properly and permanently, quickly lose its value; 2 ) is generally inflexible; and 3) if too synthetic become less useful and, on the other hand, if very detailed has the risk of obsolescence in any minor changes.

It should considered the basic requirements when preparing a manual: 1) must contain simple, concise, efficient, clear writing containing index or table of contents; 2 ) shall use the existing institutional rules; 3 ) must be flexible; and 4) must have a continuous review process, update and distribution.

When invested in the regulation of function procedures it should: 1) aim to describe and detail the development or implementation of activities or procedures that make up the various sectors of the institutions; 2) establish criteria and procedures to enable uniform implementation of services; 3 ) contain guidelines and instructions necessary for the development of certain activities that are of interest and application for all administrative units; 4) detailing the implementation of the activities that make up a system; 5) indicate what should be the circulating forms in the administrative process and there manipulation; 6) provide flow charts indicating in representative graphics the various described procedures; and 7) to add annexes (tables, documents, texts, legislation, or any other information relating to the subject)

\section{EVALUATION}

PROPOSITION FOR MANUAL CREATION AND SCORE

It is currently discussed the scope of the manual, with regard to the ISBN registration, characterizing it as a local, regional, national or international publication. Moreover, it is necessary to standardize indexes for evaluation realizing the complexity and size of the manual, the practical applicability, relevance and adherence to a variety of health services, the publication in other languages and the relevance of the publisher.

The insertion of manuals in the Lattes Platform takes place in the menu as "Productions", sub-menu "Processes and techniques" or "Development of teaching or institutional material". In the menu as "Education and Popularization in S\&T", sub-menu "Development of teaching or institutional material". 
To characterize the impact, beyond the utility and applicability in the developing site, manual scoring $(M)$ in the evaluation process of Medicine III may have the following stratification:

M4 - 100 points: with ISBN registration and disclosure in other languages:

M3 - 75 points: registration only in national ISBN;

M2 - 50 points: registered in regional libraries;

M1 - 25 points: manual used for intra- or inter-institutional groups;

MO - 0 point: manual use only in intra-departmental or teaching purposes.

\section{CONCLUSION}

The insertion, recovery and valuation of manuals are imperative considering that more and more the concept of evidence-based medicine is consolidated, allowing the preparation of protocols or guidelines. We know that the use of manuals is intended for those who DO NOT know the subject; however, it is an important tool that can minimize errors, consolidate professional conducts, optimizing resources, and allowing in consequence detailed evaluation of the subject that it is done to.

\section{RESUMO}

Poucos são os autores que se debruçam no estudo dos critérios de elaboração de manuais, sendo muitas vezes criticados pelo rigor metodológico das informações. Contudo, eles são interessantes no entender o que é errado, compreender prognóstico, na autoassistência, na prevenção de complicações, para identificar melhores serviços e informações, motivando a busca pela excelência no atendimento assistencial. Em sua elaboração devem ser valorizados os requisitos básicos de um manual, que são: 1) conter redação simples, concisa, eficiente e clara, contendo índice ou sumário; 2) utilizar as normas institucionais vigentes; 3) serem flexíveis; e 4) ter processo contínuo de revisão, atualização e distribuição. No processo de avaliação da Medicina III poderá ter os seguintes estratos: M4 - 100 pontos: registro no ISBN e divulgação em outros idiomas; M3 - 75 pontos: registro no ISBN apenas em nível nacional; M2 - 50 pontos: registrado em bibliotecas regionais; M1 - 25 pontos: manual de uso intrainstitucional por grupos interdepartamentais; M0 - 0 ponto: manual de uso intradepartamental ou de ensino. Em conclusão, sabe-se que o uso de manuais está destinado a quem não sabe do assunto; no entanto, trata-se de ferramenta importante que pode minimizar erros, consolidar condutas, otimizar recursos, permitindo avaliação criteriosa e aprofundada do tema em pauta.

Descritores - Comunicação manual. Educação médica. Sistemas de apoio às decisões administrativas.

\section{REFERENCES}

1. Guimarães MRC. Os manuais de medicina popular do Império e as doenças dos escravos: o exemplo do "Chernoviz" *. Rev Latinoam Psicopat Fund. São Paulo; 2008;11:827-40.

2. Shepperd S, Charnock D, Gam B. Helping patients access high quality health information. BMJ. 1999;319:764-6.

3. Svarstad BL, Mount JK. Evaluation of Written Prescription Information Provided in Community Pharmacies 2001: Final Report to the U.S. Department of Health and Human Services and the Food and Drug Administration [Internet]. 2001 [cited 2015 Sep 19]. pp. 1-10. Available from: URL: http://www.fda.gov/cder/reports/ prescriptionInfo/default.htm.
4. Coulter A, Entwistle V, Gilbert D. Sharing decisions with patients: is the information good enough? BMJ. 1999;318:318-22.

Received on: 19/02/2015

Accepted for publication: 12/09/2015

Conflict of interest: none

Source of funding:

Address for correspondence: Adhemar Monteiro Pacheco Jr. cropac03@terra.com.br 